\title{
Serum proteins and fractions, HDL-cholesterol and total IgG and IgE levels in cases of acute and chronic paracoccidioidomycosis
}

\author{
Proteínas séricas e frações, HDL-colesterol e níveis de IgG e IgE \\ totais na paracoccidioidomicose aguda e crônica
}

\author{
Audrey de Souza Marquez ${ }^{1,4}$, Adriana Pardini Vicentini Moreira ${ }^{2}$, Paula Cesar Leonello ${ }^{3}$, \\ Fernanda Akemi Nakanishi ${ }^{1}$ and Eiko Nakagawa Itano $^{4}$
}

\begin{abstract}
This study evaluated serum protein fractions, HDL-cholesterol, total immunoglobulin G and total immunoglobulin E levels in patients with acute and chronic paracoccidioidomycosis, by means of electrophoresis, enzymatic reaction and immunoenzymatic assay. The results demonstrated elevated levels of total immunoglobulin G, total immunoglobulin E, alpha-2 and gamma-globulins, which were more evident in acute than in chronic PCM, but no increase in HDL-cholesterol levels. There was a correlation between the levels of total immunoglobulin $\mathrm{E}$ and gamma-globulins and the alpha-2 and beta-globulin fractions in the acute form and between beta and gamma-globulins in both the acute and the chronic form. In conclusion, changes in total immunoglobulin $\mathrm{G}$ and immunoglobulin $\mathrm{E}$ levels and in the electrophoretic profile may be important markers for the prognosis and therapeutic follow-up of PCM cases, especially because protein electrophoresis is a simple laboratory test that can be applied when specific PCM serological tests are not available. In addition, levels of the gamma-globulin fraction greater than $2.0 \mathrm{~g} / \mathrm{dl}$ may suggest that the patient is developing a more severe form of PCM.
\end{abstract}

Key-words: Immunoglobulin G. Immunoglobulin E. HDL-cholesterol. Paracoccidioidomycosis. Electrophoresis. Enzyme-linked immunoSorbent assay.

\section{RESUMO}

Este trabalho avaliou as frações de proteínas séricas, HDL-colesterol e imunoglobulina $\mathrm{G}$ e imunoglobulina $\mathrm{E}$ totais em pacientes com paracoccidioidomicose aguda e crônica por eletroforese, reação enzimática e ensaio imunoenzimático. Os resultados demonstraram aumento dos níveis de imunoglobulina $\mathrm{G}$ e imunoglobulina $\mathrm{E}$ totais, alfa-2 e gama-globulinas, mais evidente na forma aguda que na forma crônica, e não nos níveis de HDL-colesterol. Houve correlação entre níveis de imunoglobulina E total e gama-globulinas e fração alfa-2 e beta-globulinas na forma aguda e entre beta e gama-globulinas nas formas aguda e crônica. Concluindo, alterações nos níveis de imunoglobulina G e imunoglobulina E totais e no perfil eletroforético podem ser importantes marcadores para prognóstico e acompanhamento terapêutico da PCM, especialmente por ser a eletroforese de proteínas um exame laboratorial simples que pode ser empregado em situações onde a sorologia específica para PCM não está disponível. Adicionalmente, níveis da fração gama-globulinas acima de 2,0g/dL podem sugerir que o paciente esteja desenvolvendo uma forma mais grave de PCM.

Palavras-chaves: Imunoglobulina G. Imunoglobulina E. HDL-colesterol. Paracoccidioidomicose. Eletroforese. Enzyme-linked immunoSorbent assay.

\footnotetext{
1. Microbiology Pos-Graduation Program, Department of Microbiology, State University of Londrina, Londrina, PR, Brazil. 2. Immunology Section, Institute Adolfo Lutz, São Paulo, SP, Brazil. 3. Department of Pathology Sciences, Fellow, PIBIC/CNPq, Biology Sciences Center, State University of Londrina, Londrina, PR, Brazil. 4. Department of Pathology Sciences, Biology Sciences Center, State University of Londrina, Londrina, PR, Brazil. 4. UNOPAR - University North of Paraná, Londrina, PR, Brazil. This work was supported by grants from FINEP, Fundação Araucária and FAEP/UEL. Address to: Dra. Eiko Nakagawa Itano. Depto. de Ciências Patológicas/CCB/UEL. Campus Universitário, 86051-970 Londrina, PR, Brazil.

Tel: 5543 3371-4469; Fax: 5543 3371-4207

e-mail: itano@uel.br

Received in 26/12/2007

Accepted in 04/06/2009
}

Paracoccidioidomycosis (PCM) is a systemic granulomatous disease caused by the dimorphic fungus Paracoccidioides brasiliensi $^{22}$. It is considered to be one of the most common systemic mycoses in Latin America, and Brazil has the greatest number of cases $^{10}$. PCM disease presents two clinically distinct forms: the acute or juvenile form (AF) and chronic or adult form $(\mathrm{CF})^{6}$. The AF is characterized by rapid clinical evolution with the involvement of multiple organs, while the $\mathrm{CF}$, which accounts for more than $90 \%$ of the patients, progresses slowly and silently for years. The multifocal CF is more severe and involves skin, mucosa, lungs and lymph node manifestations ${ }^{23}$. 
Serum protein electrophoresis is a simple laboratory test that helps to monitor patients over the course of PCM. It has already been demonstrated that, although total serum proteins may persist at normal levels, the fractionation of the serum shows a decrease in albumin levels and an increase in alpha-1, alpha-2 and gamma-globulin fractions. The variations in these parameters are also more prominent in patients with the acute form than in those with the chronic form of the disease ${ }^{17}$.

Analysis of antibody isotype expression in AF and CF PCM has demonstrated elevated levels of total IgG and IgE and of IgG, IgE or IgA specific to some Paracoccidioides brasiliensis antigens ${ }^{3516}$, while in the AF it occurs mainly by the presence of total $\operatorname{IgG}$, $\operatorname{IgG} 4$ subclass and $\operatorname{IgE}^{2314}$. High levels of total IgE and IgE anti-gp 43 have been correlated with polyclonal B lymphocyte activation, which is observed in the $\mathrm{AF}$ disease ${ }^{49}$. Cellulose-acetate electrophoresis is a simple and routine clinical laboratory procedure that could be used to improve the interpretation and evaluation of PCM patients' follow-up, taking into account the more recent immunological knowledge of this disease. In addition, since a large proportion of $\alpha$-lipoproteins, represented mainly by HDL-cholesterol, migrate into the alpha-1 globulin region and are a major contributor to this protein fraction according to capillary zone electrophoresis ${ }^{15} 18$, this parameter has also been estimated.

The present study evaluated the levels and possible correlations among serum protein fractions, HDL-cholesterol and total IgG and IgE in acute and chronic PCM patients.

\section{MATERIAL AND METHODS}

Serum samples. Serum samples from 30 chronic PCM patients (ranging from 33 to 82 years of age; all females) with unifocal or multifocal disease, who were attended at Londrina State University Clinical Hospital (Londrina, PR, Brazil), and 12 acute PCM patients (ranging from 11 to 23 years of age; seven females and five males) from the Mycosis Immunodiagnostic Laboratory, Immunology Section, Adolfo Lutz Institute, São Paulo, SP, Brazil, were used. All of the PCM patients had shown positive results in radial immune diffusion tests. The control group (NHS) consisted of 44 serum samples from healthy male and female adult individuals who had already been used as normal controls at the laboratory: all of them were negative for PCM in the IDR and ELISA tests. Informed consent was obtained from all subjects participating in this study, and the study had previously been approved by the Internal Scientific Commission and Research Bioethics Committee of Londrina State University (Londrina, PR, Brazil) and by the Research Ethics Committee of the Adolfo Lutz Institution (CEPIAL).

Enzyme-linked immunoSorbent assay for total IgE.

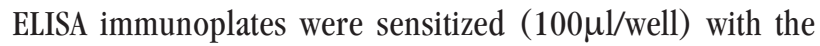
immunoglobulin fraction goat anti-human IgE (I-0632 Sigma Chemical Co, St. Louis, MO, USA) at $16 \mu \mathrm{g} / \mathrm{ml}$ in carbonate buffer ( $\mathrm{pH} 9.6$ ), for $1 \mathrm{~h}$ at $37^{\circ} \mathrm{C}$ and then overnight at $4^{\circ} \mathrm{C}$. After blockage with $5 \%$ skimmed milk in $0.5 \%$ Tween PBS buffer, the plates were washed four times using $0.5 \%$ skimmed milk in $0.05 \%$ Tween
PBS and incubated with serum samples (1:4) in 0.5\% skimmed milk in PBS for $2 \mathrm{~h}$ at $37^{\circ} \mathrm{C}$, followed by washing and incubation with goat alkaline-phosphatase anti-human IgE (A-3525 Sigma Chemical Co, St. Louis, MO, USA) diluted 1:500 (100 $\mu \mathrm{l} /$ well) for $1 \mathrm{~h} 30 \mathrm{~min}$ at $37^{\circ} \mathrm{C}$. The reaction was developed using p-nitrophenyl phosphate in diethanolamine buffer (mass/volume), at $\mathrm{pH} 9.8$ $(100 \mu \mathrm{l} /$ well $)$, with $30 \mathrm{~min}$ of incubation. The reaction was stopped with $50 \mu \mathrm{l} /$ well of $3 \mathrm{M} \mathrm{NaOH}$. The absorbance was read at $405 \mathrm{~nm}$ in a Multiskan EX reader (Labsystems, Helsinki, Finland). No significant background was observed in the reaction controls. A standard curve was produced using different dilutions of a pool of serum samples of known concentration (ng/dl).

Enzyme-Linked ImmunoSorbent Assay for total IgG. ELISA immunoplates were sensitized $(100 \mu 1 /$ well) with the immunoglobulin fraction rabbit anti-human IgG at $40 \mu \mathrm{g} / \mathrm{ml}$ and blocked as described above. Serum samples diluted 1:4 in 0.5\% skimmed milk in PBS were added (100 $\mu \mathrm{l} /$ well) and incubated for $2 \mathrm{~h}$ at $37^{\circ} \mathrm{C}$. After washing, the plates were incubated with goat anti-human IgG peroxidase conjugate (A-8775 Sigma Chemical

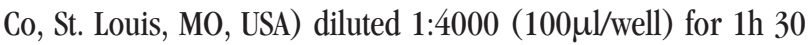
min at $37^{\circ} \mathrm{C}$, followed by washing and the addition of $10 \mathrm{mg}$ of OPD (ortho-phenylenediamine) in $25 \mathrm{ml}$ of phosphate citrate buffer ( $\mathrm{pH} 5.0)$, plus $10 \mu \mathrm{l}$ of $30 \% \mathrm{H}_{2} \mathrm{O}_{2}(100 \mu \mathrm{l} /$ well). After 15 min of incubation, the reaction was stopped with $50 \mu \mathrm{l} /$ well of $4 \mathrm{~N} \mathrm{H}_{2} \mathrm{SO}_{4}$ and the absorbance was read at 492nm in a Multiskan EX reader (Labsystems, Helsinki, Finland). The background interference (evaluated through reaction controls) was discounted from all absorbance results. A standard curve was performed using different dilutions of a pool of serum samples of known concentration (mg/dl).

High-density lipoprotein cholesterol quantification. Serum samples were analyzed using a commercial kit (Ebram Laboratory Products Ltda), by means of a direct ultra-sensitive colorimetric reaction with cholesterol oxidase in automated equipment (Selectra E, Bayer SA).

Serum protein electrophoresis. Serum samples were applied to cellulose acetate strips and electrophoresis was performed in Veronal-Sodic buffer ( $\mathrm{pH}$ 8.6-8.8) for 25 minutes, followed by $10 \mathrm{~min}$ of incubation in Ponceau $S$ stain and destaining in $5 \%$ acetic acid. All the strips were dehydrated for $1 \mathrm{~min}$ in methanol PA and clarified for $3 \mathrm{~min}$ in $85 \%$ methanol-15\% acetic acid solution. They were then dried at $80^{\circ} \mathrm{C}$ for $2 \mathrm{~min}$, read and digitized using the Glob-Al Scan II computer software (Dynaware). The quantification of total proteins was performed by means of the Biuret method. Readings were done using a spectrophotometer at $545 \mathrm{~nm}$ and expressed in $\mathrm{g} / \mathrm{dl}$.

Radial Immunodiffusion Test. The serum samples were analyzed in accordance with the protocol used by Tatibana et $a l^{4}$.

Statistical analysis. For the statistical analysis, all the variables were calculated as $\log _{10}$ values, except for total $\mathrm{IgE}$, which was calculated as SQRT values. Pearson's correlation test was applied. Significance was defined as $p \leq 0.05$ and positive correlations as $r \geq 0.50$. The correlations were taken to be strong when $r \geq 0.75$ and weak when $r>0.50$ and $<0.75$. For gamma- 
globulin fraction analysis among the groups, a box-plot graph was also performed using the Bioestat statistical software.

\section{RESULTS}

The ELISA results for total IgE showed significant differences between all of the groups $(\mathrm{p}<0.05)$. For total $\operatorname{IgG}$, the results were significantly higher in AF PCM than in CF PCM or NHS. The statistical analysis did not demonstrate any significant difference in total IgG between the CF PCM and NHS groups (Table 1). The mean values for HDL in AF PCM, CF PCM and NHS were $28.2 \pm 7.89 \mathrm{mg} / \mathrm{dl}, 29.6 \pm 10.45 \mathrm{mg} / \mathrm{dl}$ and $30.8 \pm 8.52 \mathrm{mg} / \mathrm{dl}$, respectively. In PCM patients, the mean results for HDL-cholesterol were slightly below the normal reference limits (30 to $70 \mathrm{mg} / \mathrm{dl}$ ). No correlation between HDL and serum protein fractions was observed in this study.
The protein fraction results expressed in $\mathrm{g} / \mathrm{dl}$ are summarized in Table 2. These show that the mean values for alpha-2 and gamma-globulins are elevated in CF PCM, and that total proteins and alpha-1, alpha-2 and gamma-globulins are elevated in $\mathrm{AF}$ PCM. The albumin/globulin ratio was lower in AF PCM than in CF PCM and NHS. There was no correlation between albumin and IDR results $(r=-0.1031)$.

For AF PCM, Pearson's correlation test demonstrated stronger coefficients between alpha- 1 and beta-globulins $(\mathrm{r}=0.8307)$ and between alpha-1 and gamma-globulins ( $\mathrm{r}=0.8289)$, but this was not observed in the CF PCM or NHS groups (Figures 1C and 1B). This demonstrated a weak correlation between the beta and gamma-globulin fractions $(\mathrm{r}=0.7142)$ and between gammaglobulins and total $\operatorname{IgE}(r=0.6026)$ (Figures 1A and 1D). In CF PCM, only a weak correlation between beta and gamma-globulin fractions was detected $(r=0.6506)$.

TABLE 1

Total IgG and total IgE evaluated by ELISA in patients with the chronic form and acute/subacute form of paracoccidioidomycosis and in healthy controls. Results were measured in optical density and concentrations (mg/dL and ng/dL).

\begin{tabular}{|c|c|c|c|c|}
\hline \multirow[b]{2}{*}{ Group (n) } & \multicolumn{2}{|c|}{ Total IgG } & \multicolumn{2}{|c|}{ Total IgE } \\
\hline & OD & $\mathrm{mg} / \mathrm{dL}$ & OD & $\mathrm{ng} / \mathrm{dL}$ \\
\hline (1) CF PCM (30) & $0,298 \pm 0,210^{A}$ & $1440 \pm 439^{A}$ & $0,369 \pm 0,127^{\mathrm{A}}$ & $40,38 \pm 17,63^{A}$ \\
\hline (2) AF PCM (12) & $0,424 \pm 0,122^{\mathrm{B}}$ & $1704 \pm 255^{\text {В }}$ & $0,600 \pm 0,123^{\mathrm{B}}$ & $72,45 \pm 17,02^{\mathrm{B}}$ \\
\hline (3) NHS (44) & $0,243 \pm 0,086^{A}$ & $1325 \pm 179^{A}$ & $0,154 \pm 0,073^{\mathrm{c}}$ & $10,64 \pm 10,17^{\mathrm{C}}$ \\
\hline
\end{tabular}

${ }^{\mathrm{AB}}$ Total IgG 1x2, 2x3 and ${ }^{\mathrm{ABC}}$ Total IgE $1 \times 3,2 \times 3,1 \times 2, \mathrm{p}<0,050$.

(n) number of patients or healthy individuals.

Reference values: total IgG (751 to $1,560 \mathrm{mg} / \mathrm{dL}$ in adults); total IgE (> 33,6ng/dL for individuals above 10 years old).

CF: chronic form, AF: acute/subacute form, NHS: healthy controls, PCM: pacoccidioidomycosis, OD: optical density.

\section{TABLE 2}

Serum protein profile obtained in acetate-cellulose electrophoresis in chronic and acute/subacute forms of paracoccidioidomycosis and in healthy controls (NHS), expressed in g/dL and percentages.

\begin{tabular}{|c|c|c|c|c|c|c|}
\hline & \multicolumn{2}{|c|}{ (1) CF PCM $(n=30)$} & \multicolumn{2}{|c|}{ (2) AF PCM $(n=12)$} & \multicolumn{2}{|c|}{ (3) NHS $(n=44)$} \\
\hline & $\mathrm{g} / \mathrm{dL}$ & $\%$ & $\mathrm{~g} / \mathrm{dL}$ & $\%$ & $\mathrm{~g} / \mathrm{dL}$ & $\%$ \\
\hline Total proteins & $7,60 \pm 1,303^{\mathrm{ab}}$ & 100.0 & $8,61 \pm 1,228^{a}$ & 100.0 & $7,43 \pm 1,275^{\mathrm{b}}$ & 100.0 \\
\hline Albumin & $3,64 \pm 0,779^{a}$ & $47,9 \pm 6,66$ & $3,99 \pm 0,738^{\mathrm{a}}$ & $46,85 \pm 8,11$ & $4,28 \pm 0,876^{b}$ & $57,4 \pm 4,25$ \\
\hline$\alpha 1$-globulins & $0,31 \pm 0,115^{\mathrm{ac}}$ & $4,11 \pm 1,46$ & $0,44 \pm 0,192^{\mathrm{b}}$ & $5,00 \pm 1,75$ & $0,28 \pm 0,113^{c}$ & $3,80 \pm 1,31$ \\
\hline$\alpha 2$-globulins & $1,03 \pm 0,238^{\mathrm{a}}$ & $13,62 \pm 2,52$ & $0,93 \pm 0,128^{\mathrm{ab}}$ & $10,91 \pm 1,07$ & $0,74 \pm 0,180^{c}$ & $10,01 \pm 2,03$ \\
\hline$\beta$-globulins & $0,92 \pm 0,296^{\mathrm{a}}$ & $12,06 \pm 2,76$ & $0,74 \pm 0,172^{\mathrm{bc}}$ & $8,59 \pm 1,30$ & $0,76 \pm 0,173^{\mathrm{c}}$ & $10,23 \pm 1,91$ \\
\hline$\delta$-globulins & $1,70 \pm 0,492^{\mathrm{a}}$ & $22,26 \pm 4,16$ & $2,49 \pm 0,785^{b}$ & $28,65 \pm 6,26$ & $1,37 \pm 0,289^{c}$ & $18,54 \pm 1,36$ \\
\hline Albumin/globulin & $0,919^{\mathrm{a}}$ & - & $0,864^{\mathrm{a}}$ & 一 & $1,359^{\mathrm{b}}$ & - \\
\hline
\end{tabular}

Significant horizontal comparisons between groups (1) CF PCM, (2) AF PCM and (3) NHS are expressed as different vowels (p<0,050), while the same vowels represent results not statistically different.

(n) Number of patients or healthy individuals.

Reference values from literature for each variable are: total proteins $(6,0-8,0 \mathrm{~g} / \mathrm{dL})$, albumin $(3,5-4,9 \mathrm{~g} / \mathrm{dL} ; 50$ a $68 \%), \alpha 1$-globulins $(0,1-0,4 \mathrm{~g} / \mathrm{dL} ; 2$ a $6 \%), \alpha 2$-globulins $(0,4-0,8 \mathrm{~g} / \mathrm{dL} ; 7$ a $12 \%), \beta$-globulins $(0,6-1,0 \mathrm{~g} / \mathrm{dL} ; 9$ a $16 \%)$ and $\delta$-globulins $(0,8-1,4 \mathrm{~g} / \mathrm{dL} ; 12 \mathrm{a} 22 \%)$.

CF: chronic form, AF: acute/subacute form, NHS: healthy controls, PCM: Pacoccidioidomycosis. 


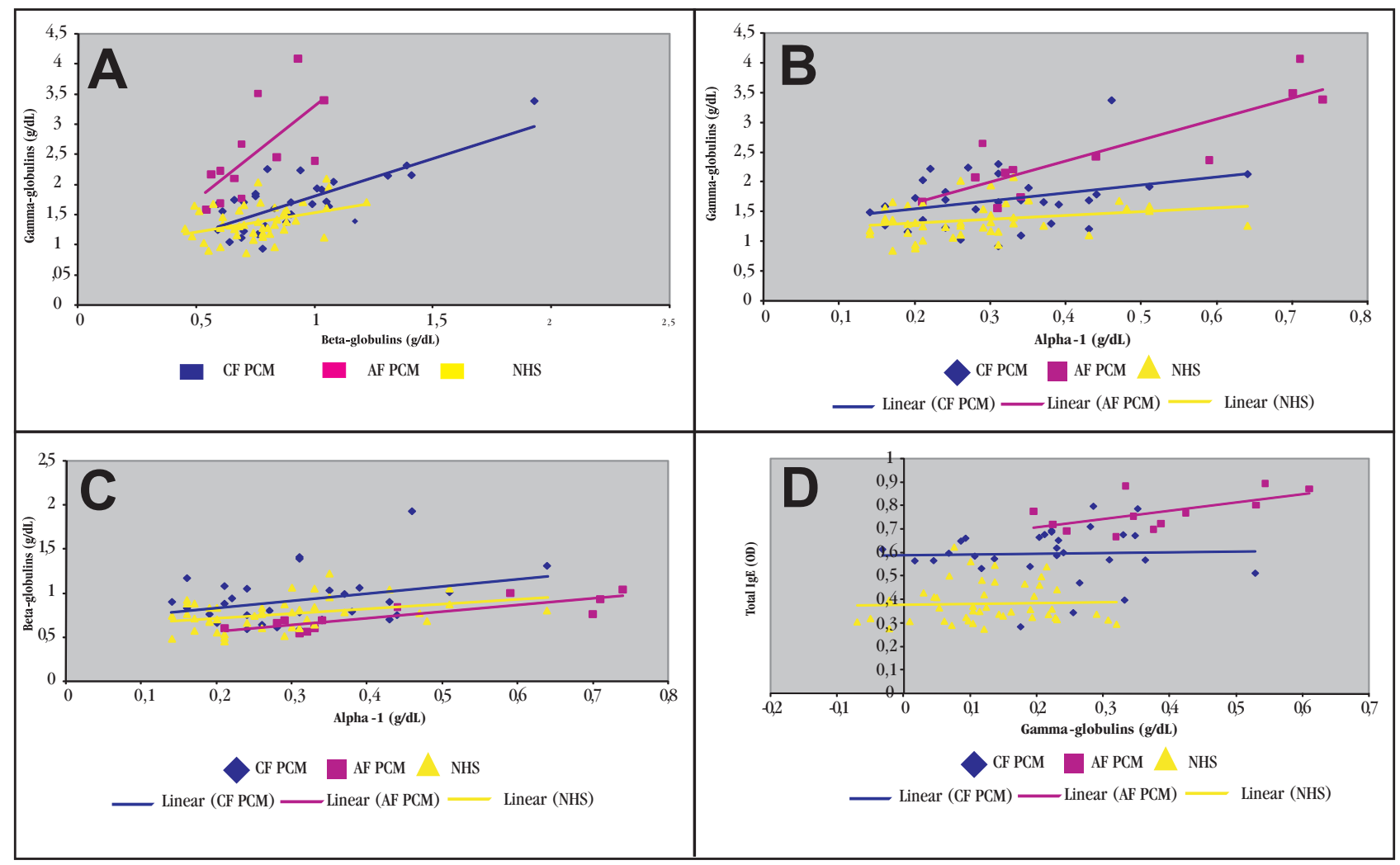

\section{FIGURE 1}

Correlations between globulins and total immunoglobulin $\mathrm{E}$, evaluated 2x2, in paracoccidioidomycosis patients with the acute/subacute (AF) or the chronic (CF) form and in healthy controls (NHS). (A) Gamma and beta-globulins in AF PCM ( $\mathrm{r}=0.7142)$, CF PCM ( $\mathrm{r}=0.6506)$ and NHS ( $\mathrm{r}=0.3369)$; (B) Gamma and alpha-1 globulins in AF PCM $(\mathrm{r}=0.8289)$, CF PCM $(\mathrm{r}=0.2685)$ and NHS $(\mathrm{r}=0.2790)$; (C) Beta and alpha-1 globulins in AF PCM $(\mathrm{r}=0.8306)$, CF PCM $(\mathrm{r}=0.2303)$ and NHS $(\mathrm{r}=0.3521) ;(\mathrm{D})$ Total IgE and gamma-globulins in AF PCM $(r=0.6026)$, CF PCM $(r=0.0284)$ and NHS $(r=0.0426)$.

\section{DISCUSSION}

Most patients with active PCM demonstrate protein abnormalities that are revealed by a simple serum protein electrophoresis test ${ }^{17}$. This test is usually used as an initial evaluation marker for patients and to follow up the treatment evolution ${ }^{1320}$. Studies on serum protein profiles for PCM patients have shown decreased albumin and increased alpha-1, alpha-2 and gamma-globulin fractions, along with reduced beta-lipoproteins in some patients, and have correlated these variations with PCM severity ${ }^{1317}$. In the present study, increased levels of alpha-2 and gamma-globulins in CF PCM and alpha-1, alpha-2 and gamma-globulins in AF PCM were described. In order to establish a cutoff value for gammaglobulins that could indicate disease severity, data analysis was performed in the Bioestat 5.0 statistical software, which revealed that every CF PCM patient had results below $2.0 \mathrm{~g} / \mathrm{dl}$, while the mean value for AF PCM patients was $2.08 \mathrm{~g} / \mathrm{dl}$. Although clinical characteristics, nutritional state and other comorbidities were not appraised in this investigation, it may be suggested through taking into account that AF PCM is considered more severe than CF $\mathrm{PCM}^{623}$, that patients with gamma-globulin laboratory results above $2.0 \mathrm{~g} / \mathrm{dl}$ are probably developing a more severe condition of the disease that requires further investigation. The albumin/ globulin ratio was also significantly different between $\mathrm{AF}$ or $\mathrm{CF}$ PCM and NHS, as expected and described in the literature ${ }^{1718}$. The reduced albumin values observed in percentages but not in absolute results, except for CF PCM patients exhibiting high titers in the IDR test (1:16 and 1:32), could be correlated with a more prominent inflammatory response and greater severity of disease state in these patients. Under other conditions, it has been proposed that the main reason for reduced albumin levels relates to synthesis of acute-phase proteins in the liver, which occurs at the expense of albumin production, and that the albumin/globulin ratio is a better parameter for distinguishing between malignant and healthy states ${ }^{1221}$.

Considering that elevated alpha-1 globulin levels were observed in the AF PCM and not the CF PCM group, we investigated the possible role of HDL in the elevation of this parameter. Our results showed that there was no significant difference in HDL levels between the AF PCM, CF PCM and NHS groups, thus demonstrating that HDL cholesterol is not expected to influence elevation of the alpha-1 globulin fraction in PCM.

The use of serological methods to detect specific antibodies is an important tool in PCM diagnosis, but the problem of antigen standardization still remains. This makes it difficult to compare the results from different laboratories and means that ensuring access to these methodologies for every clinical diagnosis laboratory is problematic $^{81119}$. In this study, higher levels of total IgG and IgE could be seen, but there was only a significant correlation between total IgE and the gamma-globulin fraction in the AF of the disease. This suggests that increased IgE levels could be a better molecular marker for severity than IgG in PCM is. 
From these results, it could be confirmed that the serum protein fraction profile changes in PCM, and that there are positive correlations between some of the protein fractions and between gamma-globulin and total IgE levels. It could also be concluded that there are differences in interpreting albumin results when expressed as percentages or absolute levels, and that HDL probably does not contribute towards the changes in the alpha-1 globulin fraction that are observed among PCM patients. In addition, levels of the gamma-globulin fraction above $2.0 \mathrm{~g} / \mathrm{dl}$ may suggest that the patient is developing a more severe form of PCM. Changes in both the serum electrophoretic profile and the total $\operatorname{IgG}$ and IgE levels may be important markers for prognostic or even treatment follow-up in PCM. Electrophoresis may be especially important, since it is a simple routine laboratory method that can be applied in regions where specific PCM serological tests are not easily available.

\section{ACKNOWLEDGEMENTS}

The authors thank Mari S. Kaminami, Nilson de Jesus Carlos and Lucinei Maria de Oliveira Brunello for their excellent technical assistance and Dr. Leonardo Sturion for his help in statistical analysis.

\section{REFERENCES}

1. Angelopoulos B, Karalis D, Tsoukantas A, Eleftheriadou A, Danopoulos E. Eletrophoretic analysis of serum proteins, glucoproteins and lipoproteins in acute infectious diseases in infants and children. International Journal of Experimental and Clinical Pharmacology 14: 517-527, 1966

2. Arango M, Yarzábal L. T-cell dysfunction and hyperimmunoglobulinemia E in paracoccidioidomycosis. Mycophatologia 79: 115-124, 1982.

3. Baida H, Biselli PJC, Juvenale M, Del Negro GMB, Mendes-Giannini MJS, Duarte AJS Benard G. Differential antibody isotype expression to major Paracoccidioides brasiliensis antigen in juvenile and adult form paracoccidioidomycosis. Microbes and Infection 1: 273-278, 1999.

4. Biselli PJ C, Juvenale M, Mendes-Giannini MJS, Duarte AJS, Benard G. IgE antibody response to the main antigenic component of Paracoccidioides brasiliensis in patients with paracoccidioidomycosis. Medical Mycology 39: 475-478, 2001.

5. Blotta MHSL, Camargo ZP. Immunological response to cell-free antigens of Paracoccidioides brasiliensis: relationship with clinical forms of paracoccidioidomycosis. Journal of Clinical Microbiology 31: 671-676, 1993.

6. Brummer E, Castaneda E, Restrepo A. Paracoccidioidomycosis: an Update. Clinical Microbiology Reviews 2: 89-117, 1993.

7. Cano LE, Gomez B, Brummer E, Restrepo A, Stevens DA. Inhibitory effect of deferoxamina or macrophage activation on transformation of Paracoccidioides brasiliensis conidia ingested by macrophages: reversal by holotransferrin. Infection and Immunity 62: 1494-1496, 1994.
8. Cano LE, Restrepo A. Predictive value of serologic tests in the serodiagnosis and follow up of patients with paracoccidioidomycosis. Revista do Instituto de Medicina Tropical de São Paulo 29: 276-283, 1987.

9. Chequer-Bou-Habib D, Daniel-Ribeiro C, Banic DM, Valle ACF, Galvão-Castro B. Polyclonal B cell activation in paracoccidioidomycosis. Mycopathologia 108: 89-93, 1989.

10. Coutinho ZF, Silva D, Lazéra M, Petri V, Oliveira RM, Sabroza PC, Wanke B. Paracoccidioidomycosis mortality in Brazil (1980 - 1995). Caderno de Saúde Pública 18: 1441-1454, 2002.

11. Díez S, Gómez BL, McEwen RJ, Restrepo A, Hay RJ, Hamilton AJ. Combined use of Paracoccidioides brasiliensis recombinant 27-kilodalton and purified 87 kilodalton antigens in an enzyme-linked immunosorbent assay for serodiagnosis of paracoccidioidomycosis. Journal of Clinical Microbiology 41: 1536-1542, 2003.

12. Hedlund JU, Hansson LO, Ortqvist AB. Hypoalbuminemia in hospitalized patients with community-acquired pneumonia. Archives of Internal Medicine 155: 1438 $1442,1995$.

13. Hildebrand TM, Rosário Filho NA, Queiroz-Telles Filho F, Costa O, Miasaki N, Mira JGS, Miyaki M. Paracoccidioidomicose na criança. Aspectos clínicos e laboratoriais em 25 casos. Jornal de Pediatria 63: 92-97, 1987.

14. Hostetler JS, Brummer E, Coffman RL, Stevens DA. Effect of anti-IL-4, interferongamma and antifungal triazole (SCH 42427) in paracoccidioidomycosis: correlation of IgE levels with outcome. Clinical and Experimental Immunology 94: 11-16, 1993 .

16. Luraschi P, Pagani A, Infusino I, Moraschinelli I, Franzini C. High-density lipoproteins contribute to the $\alpha$-1-globulin zone in capillary electrophoresis of human serum proteins. Electrophoresis 25: 1551-1554, 2004.

16. Marquez AS, Vicentini AP, Ono MA, Watanabe MAE, Camargo ZP, Itano EN. Reactivity of antibodies from patients with acute and chronic paracoccidioidomycosis to a high molecular mass antigen from Paracoccidioides brasiliensis. Journal of Clinical Laboratory Analysis 19: 199-204, 2005.

17. Martinez R. Other laboratory tests: hematologic and biochemical changes. In: Franco M, LacazCS, Restrepo-Moreno A, Del-Negro G (eds) Paracoccidioidomycosis, $1^{\text {st }}$ ed., Boca Raton, Florida: CRC Press, p. 109-120, 1994.

18. McPherson RA. Specific proteins. In: Henry JB, Clinical Diagnosis and Management by Laboratory Methods, $19^{\text {th }}$ edition. WB Saunders Company, Philadelphia, p.237-252, 1996.

19. Mendes-Giannini MJS, Del Negro GB, Siqueira AM. Serodiagnosis. In: Franco M, Lacaz CS, Restrepo A and Del Negro G, Paracoccidioidomycosis, $1^{\text {st }}$ edition, Boca Raton, Florida: CRC Press, p.354-363, 1994.

20. Nogueira MGS, Andrade GMQ, Tonelli E, Diniz SN, Goes AM, Cisalpino PS. Laboratory evolutive aspects of children under paracoccidioidomycosis treatment. Revista da Sociedade Brasileira de Medicina Tropical 39: 478-483, 2006.

21. Rasouli M, Okhovatian A, Enderami A. Serum proteins profile as an indicator of malignancy: multivariate logistic regression and ROC analysis. Clinical Chemistry and Laboratory Medicine 43: 913-918, 2005.

22. San-Blas G. Paracoccidioidomycosis and its etiological agent Paracoccidioides brasiliensis. Journal of Medical and Veterinary Mycology 31: 99-113, 1993.

23. Shikanai-Yasuda MA, Telles Filho FQ, Mendes RP, Colombo AL, Moretti ML and Group of Consulters in Paracoccidioidomycosis. Guidelines in paracoccidioidomycosis. Revista da Sociedade Brasileira de Medicina Tropical 39: 297-310, 2006.

24. Tatibana BT, Sano A, Uno J, Kamei K, Igarashi T, Mikami Y, Miyaji M, Nishimura K, Itano EN. Detection of Paracoccidioides brasiliensis gp 43 gene in sputa by Loop-Mediated Isothermal Amplification method. Journal of Clinical Laboratory Analysis 23: 139-143, 2009. 